Clim. Past Discuss., https://doi.org/10.5194/cp-2018-29

Manuscript under review for journal Clim. Past

Discussion started: 3 April 2018

(c) Author(s) 2018. CC BY 4.0 License.

\title{
Past, present and future biomes in Beringia: Comparison between simulations and pollen analysis
}

\author{
Kazuyuki Saito ${ }^{1,2}$, Amy Hendricks ${ }^{1}$, John Walsh ${ }^{1}$, Nancy Bigelow ${ }^{3}$ \\ ${ }^{1}$ International Arctic Research Center, University of Alaska Fairbanks, Fairbaks, Alaska 99775, U.S.A. \\ 5 2Japan Agency for Marine-Earth Science and Technology, Yokohama, 236-0001, Japan \\ ${ }^{3}$ Alaska Quaternary Center, University of Alaska Fairbanks, Fairbaks, Alaska 99775, U.S.A. \\ Correspondence to: Kazuyuki Saito (ksaito@jamstec.go.jp)
}

Abstract. Past, present and future biomes in Beringia, a region including Alaska and Eastern Russia, were simulated using an equilibrium vegetation model, BIOME4 and a statistical downscaling method in order to illustrate their geographical and temporal changes. Outputs form five CMIP5 models were utilized to represent the climate for four time periods, i.e., the Last Glacial Maximum (LGM; 21ka), the mid-Holocene Optimum (6ka), the modern period, and the near future (the end of this century under a RCP8.5 scenario). Present-day biome simulations were generally consistent with current vegetation observations in the study region. Pollen samples indicate that the Bering Land Bridge was covered almost entirely by cushionforb and graminoid tundra during the LGM, whereas the paleoclimate simulations show large across-model variations in this region. Three out of the five models' climate data produce evergreen and deciduous taiga at $21 \mathrm{ka}$ in what is now southwestern Alaska and southeastern Bering continental shelf. The $6 \mathrm{ka}$ simulations are in better agreement with pollen-based distributions of biomes. Future simulations show a general northward shift of biomes, including intrusions of cool and warm-temperate mixed, and cool coniferous forests above $60^{\circ} \mathrm{N}$, especially in southwest Alaska.

\section{Introduction}

\subsection{Arctic Climate-Vegetation-Permafrost Interaction}

The Arctic is a complex system governed by interactions between individual components including the atmosphere, terrestrial ecosystems, cryosphere, and ocean. The Arctic climate is characterized by large spatial variability and extreme annual temperature ranges, which are controlled by incoming solar radiation over the year (Serreze and Barry, 2014; Arctic Climate Impact Assessment (ACIA), 2005). Because cooler air is capable of holding less water than warmer air, precipitation in the 25 Arctic is generally low (NSIDC, accessed on March 22, 2018) and varies across locations: e.g., from the Alaskan panhandle to high Arctic regions (Bieniek et al., 2012). Arctic vegetation is an integral part of the Arctic system that is controlled largely by temperature and length of growing season (Chapin and Körner, 1995; Chapin et al., 1992; Circumpolar Arctic Vegetation Map [CAVM] Team, 2003). Ambient conditions also influence the survival and succession of the vegetation in the terrestrial Arctic. It is widely recognized that climate, vegetation, and permafrost constitute a tightly coupled system in the cryosphere, 
Clim. Past Discuss., https://doi.org/10.5194/cp-2018-29

Manuscript under review for journal Clim. Past

Discussion started: 3 April 2018

(c) Author(s) 2018. CC BY 4.0 License.

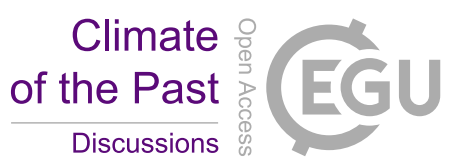

which is characterized by a large temporal spectrum of interactions, including thresholds associated with the phase change between liquid and frozen water. Permafrost, defined as ground that is subject to temperatures at or below freezing for at least two consecutive years (van Everdingen, 2005), underlies the majority of the circum-Arctic region (Saito et al., 2013a; Callaghan et al., 2011; Romanovsky et al., 2010, 2017; Zhang et al. 1999). Permafrost is modified or controlled by surface 5 conditions (Walker et al., 2003; Cannonne et al., 2006; Shur and Jorgenson, 2007; Saito et al., 2013a). The type of vegetation can alter subsurface thermal regime and thickness of active layer (i.e., top ground layer that thaws seasonally) in the Arctic (Walker et al., 2003), as well as in Antarctica (Cannonne et al., 2006). Soil layers with high organic carbon content (i.e., peat layers) form in the boreal or tundra regions. Dense plant canopies and/or thick soil organic horizons provide extra insulation. In turn, the presence of permafrost strongly affects vegetation by providing a physical foundation for roots and a higher ground

10 water level, albeit with colder soil temperatures. A vegetation shift, either natural or anthropogenic, at a given point may help to maintain or degrade the permafrost layer through subsequent thickening or thinning of the organic layer. The type of permafrost and ambient conditions can also determine how permafrost will react to changes in vegetation. Other factors that impact permafrost include elevation, slope, aspect, snow cover, bodies of water, and infrastructure (Romanovsky et al., 2010, 2017; Callaghan et al., 2011; Saito et al., 2013a). Arctic regions are more sensitive to climate change than the lower and middle

15 latitudes (IPCC, 2013).

\subsection{Past Climate}

Over the Late Quaternary period, from the latter part of the Late Pleistocene (126 thousand years ago to 11.7 thousand years ago) and Holocene (11.7 thousand years ago to the present), the earth has experienced large changes in climate driven primarily by changes in the orbital parameters of the earth-sun system. These climate changes influenced both the vegetation and

20 permafrost distributions. Much of the permafrost present today formed in the Late Pleistocene glacial period and persisted through deglaciation periods (Frenzel et al., 1992; French, 2007; Saito et al. 2013b).

\subsubsection{Last Glacial Maximum}

The Last Glacial Maximum (LGM), or 21 thousand years ago (ka) as the corresponding timeframe for the simulations, was a period of widespread ice advance (Ehlers et al., 2011), although in Beringia (the region between the Mackenzie River in the 25 east to the Verkhoyansk mountains in the west), ice advance was generally limited to alpine regions. (Fig. 1). Ice advance was limited by a combination of low moisture availability and possibly warm summers (Briner and Kaufman, 2008). Vegetation across Beringia was a sparse graminoid-rich tundra with few shrubs (Bigelow, 2013; Anderson et al., 2004; Lozhkin and Anderson, 2007). However, local and regional temperature and moisture gradients probably resulted in a mosaic of more and less abundant vegetation, depending on variables such as summer warmth, moisture availability, and ground surface

30 disturbance. Loess production from the glacially-fed streams was high, although loess deposition was relatively low as the vegetation was not an efficient sediment trap (Muhs et al., 2003). Pleistocene sand seas were active and widespread across Alaska (Hopkins, 1982) and lakes were virtually absent in the driest regions. There was probably a moisture gradient from 
Clim. Past Discuss., https://doi.org/10.5194/cp-2018-29

Manuscript under review for journal Clim. Past

Discussion started: 3 April 2018

(c) Author(s) 2018. CC BY 4.0 License.

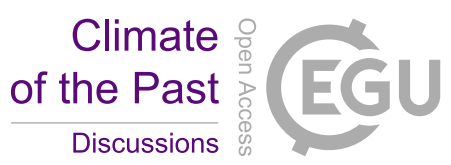

the arid east to the less arid west, as pollen records hint at increased abundance of relatively mesic taxa in western localities (Bigelow, 2013). In addition, vegetation and beetle records from the terrestrial sediments on the now submerged central Beringia, indicate a relatively mesic environment there (Elias and Crocker, 2008; Elias et al., 1997), although dating uncertainties (mesic samples could in fact date to a younger time period) confuse interpretations.

5

In eastern Beringia, temperature reconstructions based on pollen (Viau et al., 2008) and chironomids (Kurek et al., 2009) indicate a modest $2-4^{\circ} \mathrm{C}$ depression in summer temperatures. General circulation models (GCMs) suggest temperatures in Beringia were $5^{\circ}-10^{\circ} \mathrm{C}$ cooler for all seasons of the year, with coolest regions adjacent to ice sheets; modelled precipitation was more arid than today, with annual precipitation 18-35 cm less than modern (https://pmip3.lsce.ipsl.fr/; PMIP 3 Home > Model Database $>$ Maps $>21 \mathrm{~K}$ ).

\subsubsection{Mid-Holocene}

By the mid-Holocene (similarly, 6ka for the simulations), sea level and the locations of the coastlines were similar to the present. $\mathrm{CO}_{2}$ concentrations had increased to about $280 \mathrm{ppm}$. Parts of the northern hemisphere (especially Europe and eastern North America) were warmer than modern as measured by changes in temperature-sensitive proxies from both marine and 15 terrestrial sites (Kaufman et al., 2004; Bartlein et al., 2011; Renssen et al., 2012). In Beringia, however, there is little to suggest increasing warmth during the mid-Holocene. The vegetation is similar to modern and there is no evidence of a tree-line advance (Bigelow et al., 2003). Temperature reconstructions based on pollen data show a similar pattern with muted, if any, warming in Beringia and $70 \%$ of the Beringian pollen sites reconstruct summer temperature as not significantly different from today (Bartlein et al., 2011). The PMIP3 ensemble map, based on a suite of 14 GCMs, indicates slightly warmer summers

20 (max $1^{\circ} \mathrm{C}$ warming) and slightly cooler winters ( $\max 0.5^{\circ} \mathrm{C}$ cooling) in Beringia relative to today, resulting in a mean annual temperature that is similar to modern; precipitation for the same GCM suite was similar to modern throughout the year (https://pmip3.lsce.ipsl.fr/; PMIP 3 Home > Model Database > Maps > 6K).

\subsection{Content of the paper}

This study attempts to understand the sensitivities of Arctic vegetative distributions to climate forcings of the past and how

25 Arctic vegetation distributions could potentially change in the future with a changing climate. We do so by comparing the Arctic flora simulated by an equilibrium biome model (BIOME4, Kaplan et al., 2003) for three historical periods in the late Quaternary (the Last Glacial Maximum, the Holocene Optimum, and the modern day) and a future projection. In this paper, we will show the evolution of vegetation in the Bering land bridge region simulated by a global equilibrium biogeochemistrybiogeography model (BIOME4) driven by the outputs from five GCMs for the late Quaternary period and near-future. After

30 providing the methodologies of this study, we will show the results of the historical vegetation simulations and their validation with the historical records (i.e., pollen data). We then present a future projection for to assess the potential vegetative impacts 
Clim. Past Discuss., https://doi.org/10.5194/cp-2018-29

Manuscript under review for journal Clim. Past

Discussion started: 3 April 2018

(c) Author(s) 2018. CC BY 4.0 License.

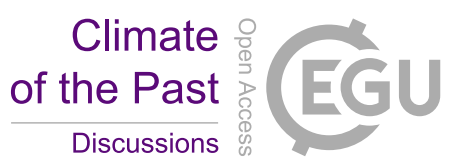

of climate change under a business-as-usual scenario. A sensitivity analysis of the biome model follows in order to understand the major driving factors of the vegetation change, including a discussion of implications for feedbacks to high-latitude climate.

\section{Methods}

\subsection{Study Region}

5 The study region (Fig. 1) was defined as the land area bounded by $50^{\circ} \mathrm{N}$ (southern limit), $80^{\circ} \mathrm{N}$ (northern limit), $140^{\circ} \mathrm{E}$ (western limit), and $120^{\circ} \mathrm{W}$ (eastern limit). These boundaries encompass Beringia, which experienced large changes in climate, geography, and vegetation during the Quaternary (Hopkins et al., 1982; Kaplan et al., 2003; Bigelow et al., 2003). All of the biome simulations were performed on a grid of points with $0.5^{\circ}$ by $0.5^{\circ}$ resolution. Land areas are defined as those grid cells in which the land surface fraction is greater than fifty per cent. Although the coastlines thus defined are rougher than the actual, the modelled coastlines approximated the land areas reasonably well at the prescribed resolution. For the LGM simulations, the land areas expanded due to drop of sea level, which was assumed to be $127 \mathrm{~m}$ (Clark and Mix 2002; Milne and Mitrovica 2008) The LGM shoreline is drawn by thick line in Figure 1a.

\subsection{Climate Data}

The baseline modern climatology was compiled from the University of Delaware temperature and precipitation data (Matsuura and Willmott, 2009a, 2009b) and the European Center for Medium-range Weather Forecasts's (ECMWF) ECMWF Reanalysis-40 (ERA-40) solar radiation data (Uppala et al., 2005). Long-term monthly mean values of temperature and precipitation (version 2.01) were compiled by the University of Delaware from global station data (Matsuura and Willmott, 2009a, 2009b). The temperature and precipitation climate data were available at a $0.5^{\circ} \times 0.5^{\circ}$ resolution. Monthly means of daily values of solar radiation data from ECMWF's ERA-40 (1957-2002), originally at a $2.5^{\circ} \times 2.5^{\circ}$ resolution, were 20 interpolated to the same $0.5^{\circ} \times 0.5^{\circ}$ grid as the temperature and precipitation data. The modern-day observational climatology was based on the data for the years $1959-2000$.

Climate model output from the Coupled Model Intercomparison Project Phase 5 (CMIP5, Taylor et al., 2012) and Paleoclimate Modeling Intercomparison Project Phase 3 (PMIP3, Braconnot et al., 2012) was obtained through the Earth System Grid 25 Federation portal (Table 2.1). All GCM output was interpolated to $0.5^{\circ} \times 0.5^{\circ}$ globally. The models used in this project were chosen based on the climate variables available for each of the four time slices so that the same variables from each model can be used for consistency. There were five models with the required output available: CCSM4 (Gent et al., 2011); GISS-E2-R (Schmidt et al., 2014); MIROC-ESM (Watanabe et al., 2011); MPI-ESM (Brovkin et al., 2013); MRI-CCSM3 (Yukimoto et al., 2012). The variables used are surface air temperature, precipitation, surface downwelling shortwave radiation, and surface

30 down-welling clear-sky shortwave radiation. The pre-industrial era (AD 1850) is used as a baseline for the impacts that humans have had on climate. 
Clim. Past Discuss., https://doi.org/10.5194/cp-2018-29

Manuscript under review for journal Clim. Past

Discussion started: 3 April 2018

(c) Author(s) 2018. CC BY 4.0 License.

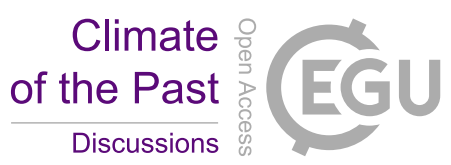

The lengths of the model simulations used here varied with the availability of the output from the various models. Table 1 shows that the paleo simulation periods ranged from 25 to 301 years, while the pre-industrial simulations ranged in length from 25 to 500 years. For the future simulations under the Representative Concentration Pathways (RCP) 8.5, three GCMs

5 (CCSM4, MIROC-ESM, MRI-CGCM3) provided climate data for the entire $21^{\text {st }}$ century up to 2100 . In these cases, the data were averaged over the whole period. MPI-ESM climate data were for the latter part of the $21^{\text {st }}$ century, from $2070-2100$, and GISS-E2-R climate data were for the early part of the $21^{\text {st }}$ century, from $2006-2025$. However, the use of different time periods precludes a systematic comparison of the across-model changes, as the late-century forcing is considerably stronger than the early-century forcing in the RCP 8.5 scenario.

10

Climate models are subject to systematic errors, including model-specific biases that can limit the validity of direct applications of the model output. The biases were removed in this study by an application of so-called "delta" method, in which a model's change (delta), relative to a benchmark period, in a variable at a particular location and month is added to the observationallybased mean value of the same variable for the same location and calendar month. The delta is computed as the change from the period of the model's modern-day climatology to a past or future time slice.

\subsection{BIOME4 Model}

BIOME4 simulates steady state biome distributions under given climate conditions. The simulations were run on a $0.5^{\circ} \times 0.5^{\circ}$ latitude/longitude grid for the whole globe, after which we focused the results on the bounded study region (Figure 1). BIOME4 is driven by long-term mean monthly climate data and soil texture information. Compared to other vegetation models that

20 calculate transient vegetation pattern changes or energy or nutrient fluxes, BIOME4 is a steady-state (equilibrium) model, making it preferable for the present application in which the available forcing data from the LGM and mid-Holocene period is in the form of climatological averages (i.e., there is no transient component within each paleo time slice). The climate variables required to force BIOME4 are long-term mean monthly temperature, precipitation, and percent sunlight. Water holding capacity and percolation rates are calculated from the soil texture information provided by the Food and Agriculture Organization of the United Nations (FAO) digital soil map (as used by Kaplan et al., 2003). Carbon dioxide values are prescribed at the beginning of each model run and remained constant for each time period.

BIOME4 calculates plant functional types (PFTs) from the above-mentioned climate data. PFTs are classifications of plants based on life form, leaf morphology, phenology, and mechanism of extreme cold tolerance (Bigelow et al., 2003). After PFTs are calculated, BIOME4 ranks tree and non-tree PFTs that were calculated within a grid cell, using variables such as net primary productivity (NPP), leaf area index (LAI), and mean annual soil moisture, which are internally calculated in BIOME4 (Kaplan et al., 2003). Based on the ranking combinations, a biome is assigned to each grid cell. BIOME4 has a total of 27 biomes that can be assigned to a grid cell globally. BIOME4 has been optimized for modern Arctic simulations and as such 
Clim. Past Discuss., https://doi.org/10.5194/cp-2018-29

Manuscript under review for journal Clim. Past

Discussion started: 3 April 2018

(c) Author(s) 2018. CC BY 4.0 License.

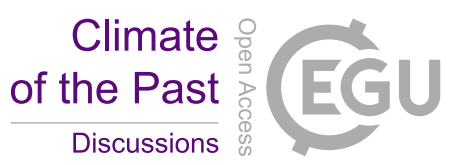

has five distinct tundra biomes, which were not present in the previous version BIOME3 (Haxeltine and Prentice, 1996). These tundra biomes are: cushion-forb tundra; prostrate shrub tundra; dwarf shrub tundras; low and high shrub tundra, and graminoid and forb tundra tundra. Definitions and examples of these tundra types can be found in Table 1 of Kaplan et al. (2003) (see also Table 4 of Bigelow et al. (2003)). In addition to the tundra biomes, BIOME4 has two Arctic tree biomes, evergreen taiga 5 (e.g., Picea glauca, Picea mariana) and deciduous taiga (e.g., Betula papyrifera, Populus tremuloides, Populus balsamifera, Larix laricina). The comparison table of the biome nomenclature used in this study and those used in BIOME4 calculations and its parental project (the BIOME 6000; Prentice and Webb, 1998) is summarised as Table 2.

\subsection{Validation and Pollen Mapping}

To validate the BIOME4 results, we converted pollen data to biomes ("biomised") by combining pollen taxa into plant 10 functional types (PFTs) and assigning the PFTs to biomes (Prentice et al., 1996). We followed Bigelow et al. (2003) for this method. Raw pollen data (terrestrial trees, shrubs, and herbs, only) were first converted to percentages. To reduce the effects of long-distance transport, only those taxa with an abundance $>0.5 \%$ were included in the analysis. We square-root transformed the percentage data to reduce the influence of high pollen producers (most wind-pollenated trees) and to increase the influence of low pollen producers (most tundra plants). Finally, one taxon that is wildly under-represented in the pollen record (Larix),

15 was given a $15 \mathrm{X}$ weight as this gave the most realistic reconstruction of the modern larch forest in eastern Siberia. These transformed pollen data are then assigned to PFTs based on the definition of each PFT. The PFT scores are then assigned to the appropriate biome and the biome with the highest total score "wins". See Prentice et al., 1996 for a detailed explanation of the method.

Pollen samples used in this analysis include all the samples in Bigelow et al. (2003) as well as samples from sites published more recently. The entire dataset (2844 samples), which spans the Arctic, was biomised, though only 1166 samples fall within the region of interest (between $140^{\circ}$ and $-120^{\circ}$ longitude and north of $55^{\circ} \mathrm{N}$ ). The data set, together with lists of all the sites in this biomisation procedure, are archived at the IARC Data Center (the URL is provided at the Data accessibility section). New samples were assessed using the same dating quality control as in Bigelow et al. (2003) (i.e., continuous or discontinuous sedimentation and age of the dated horizon relative to the time slice of interest). For the modern and mid-Holocene time slices, we chose the sample closest to the target age if it fell within 500 years of the target. Age models were either the investigator's preferred age model, or simply a linear interpolation between the dates closest to the time period of interest.

To test how well the modern biomised pollen data reflects the actual vegetation, we assigned modern biomes to each site, which was based on the vegetation descriptions provided by the analyst, either in a publication or in the site metadata if the pollen data came from a database. If no vegetation data were available, then published vegetation maps (cf. CAVM Team,

30 2003; Boggs et al., 2014a; Boggs et al., 2014b, or Haxeltine and Prentice, 1996) or nearest neighbours were used to assign a biome.

For the mid-Holocene, the sample closest to $6000{ }^{14} \mathrm{C}$ yrs ago was chosen for the analysis. While $6000{ }^{14} \mathrm{C}$ yr calibrates to about $6800 \mathrm{cal}$ yr, we did not convert the mid-Holocene dataset to 6000 calibrated yrs because this would have resulted in 
Clim. Past Discuss., https://doi.org/10.5194/cp-2018-29

Manuscript under review for journal Clim. Past

Discussion started: 3 April 2018

(c) Author(s) 2018. CC BY 4.0 License.

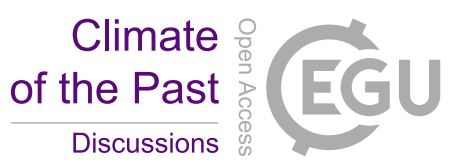

the loss of many samples from western Beringia. In addition, when the two time slices were compared for sites having both $6000{ }^{14} \mathrm{C}$ yr and $6000 \mathrm{cal}$ yr samples (260 sites in the entire arctic dataset, 65 sites in Beringia), the results were similar $(76.9 \%$ unchanged in the entire dataset and $81.5 \%$ unchanged in the Beringia dataset).

Following Bigelow et al. (2003), rules selecting LGM samples were slightly more relaxed than for the mid-Holocene. We

5 chose samples within 1000 years of $18,000{ }^{14} \mathrm{C}$ yr or 21,000 cal yr. In addition, several sites have multiple LGM samples in the dataset, either because they reflect actual variability in the vegetation, cf. the Kitluk soil (Fig. 1), a buried soil dated to $21,000 \mathrm{yr}$ BP that has multiple pollen samples (Wolf, 2001), or because the dating control is poor and it is unclear which sample falls closest to the time slice, though it is clear the group of samples dates to the LGM (c.f. Norton Sound and Burial Lake [Ager and Phillips, 2008; Abbott et al., 2010]). In all, for this analysis that spans Beringia, there are 890 modern samples,

10151 mid Holocene samples, and 78 LGM samples.

As we use pollen-based biomes to evaluate the historical results, we need to evaluate their accuracy with the modern vegetation. Within Beringia, the pollen-based biomes are correct $60.2 \%$ of the time $(n=937)$. Pollen-based biomes identified evergreen taiga correctly $93.7 \%$ of the time $(n=269)$, although the frequency of correct calls for the various kinds of shrub tundra were lower (low and high shrub tundra $48.8 \%$ correct, $n=432$; erect dwarf shrub tundra $45.5 \%$ correct, $n=110$; prostate dwarf shrub tundra $21.1 \%$ correct, $n=19$ ). Mismatches are generally due to wide dispersal of alder pollen, so that some areas biomised as low and high shrub tundra when in fact the vegetation was taiga (23.1\%), cold deciduous forest (15.7\%), or erect dwarf shrub tundra $(9.7 \%)$.

\section{Results and Discussion}

\subsection{Modern Biome Reconstruction and Validation}

The simulated modern biome (Fig $2 \mathrm{a}$ ) is generally realistic at a $0.5^{\circ} \times 0.5^{\circ}$ resolution based on a visual analysis. The majority of vegetation simulated in the study region consists of low and high shrub tundra, erect dwarf shrub tundra, prostrate dwarf shrub tundra, evergreen taiga (cold evergreen needleleaf forest in the homogenized nomenclature. See Table 2.), and deciduous taiga (similarly, cold deciduous forest). Small regions of cushion-forb tundra and temperate grassland are simulated, as well as the warmer biomes, such as cool and temperate conifer forests, and cool- and warm-temperate mixed forests in the southeastern portion of the study area. This is consistent with present day observed biomes (Viereck and Little, 1972) and pollen-based (Fig $2 b$ ) reconstructions (). That growing season length and summer temperatures drive Arctic vegetation (CAVM Team, 2003) can be consistently seen in the modern biome reconstruction and the observed biome gradients. Colder erect dwarf shrub and prostrate dwarf shrub tundra are simulated along the Arctic coast, with warmer low and high shrub tundra at lower latitudes and farther inland. However, there are major differences from actual present-day vegetation. The most noticeable is evergreen taiga and deciduous taiga simulated north of the Brooks Range in northern Alaska and along the western portion of Alaska. Figure $2 \mathrm{~b}$ shows that tundra rather than taiga exists in these regions. This can partly owe to BIOME4 model's less skilful performance in high-latitude, hyper-maritime regions with heavy cloud cover and low sun angles (Kaplan et al., 
Clim. Past Discuss., https://doi.org/10.5194/cp-2018-29

Manuscript under review for journal Clim. Past

Discussion started: 3 April 2018

(c) Author(s) 2018. CC BY 4.0 License.

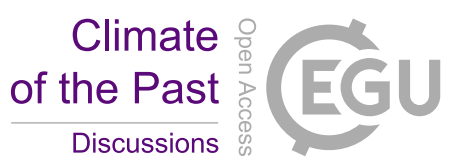

2003). It may also stem from climate data interpolated to cover a large area from a sparse station network, which produced inaccurate values in the areas. Evergreen taiga in Alaska and both evergreen taiga and deciduous taiga in eastern Russia are simulated at lower latitudes and farther inland relative to the pollen distribution. In eastern Russia, evergreen taiga dominates the southern and eastern portions of the region, while deciduous taiga is simulated in the interior region. The simulated percent of total land area covered by these biomes are: cushion-forb tundra 1\%; shrubby tundras (includes low and high shrub, erect dwarf shrub, and prostrate dwarf shrub biomes) $25 \%$; evergreen taiga $57 \%$; deciduous taiga $12 \%$; cool conifer forest $2 \%$. All other biomes including land ice make up the remaining $3 \%$ of land area.

\subsection{Historical and Future Simulations}

We conducted a series of simulations for three historical periods and one future projection. Three periods are the Last 10 Glacial Maximum (21ka), the mid-Holocene (6ka), and pre-industrial period, in correspondence to the PMIP3/CMIP5 configurations. The RCP8.5 scenario runs are used for the future projection.

The model simulations for the LGM, mid-Holocene and preindustrial periods are equilibrium simulations, i.e., with temporally invariant solar forcing, $\mathrm{CO}_{2}$ concentrations and sea level corresponding to $21 \mathrm{ka}, 6 \mathrm{ka}$ and 1850 . By contrast, $\mathrm{CO}_{2}$ concentrations increase with time during the "transient" future (RCP 8.5) simulation. The pollen data, on the other hand, span

15 a range of centuries for the LGM and mid-Holocene.

\subsubsection{Last Glacial Maximum}

The simulated biome distributions for the LGM are shown in Figure 3. The composite, model-ensemble map (Figure 3a) based on a majority-win selection rule (i.e., three out of five models need to agree to produce a biome at a grid, otherwise left as "no consensus") shows that major agreements between the models include graminoid and forb tundra along the northern shelf region; cushion-forb tundra simulated across central-interior Beringia; low and high shrub, erect dwarf shrub, and prostrate dwarf shrub tundra across eastern-interior Beringia. The pollen map shows the study region consisted of mostly graminoid and forb tundra with a few prostrate dwarf and erect dwarf shrub tundras (Figure 3b). Considering the dry and cold environment of the then-Arctic, the absence of cushion-forb tundra" may suggest that such extreme conditions were not favourable for sedimentation, pollen production, or pollen preservation (Bigelow et al. 2003, Kaplan et al., 2003).

The marked difference of the LGM biome map, compared to the other four time periods, is higher variability across the models (Figure 3c-g), reflecting the across-model differences in the simulated warm-season temperatures (not shown). Some models (i.e., CCSM4, GISS-E2-R, and MIROC-ESM) display cooler temperatures (and, hence, lower GDD 0 , or growing degree-day index above $0^{\circ} \mathrm{C}$ ) over non-glaciated regions, while others (MPI-ESM and MRI-CGCM3) show warmer than modern temperatures in the central and northern areas of the land bridge. This may partly stem from a technical limitation of 30 the delta method applied to the now-submerged ocean regions. Bartlein et al. (2015) argued that the exposed land bridge, especially in the central part, was warmer than present due to heat capacity differences between land and water. 
Clim. Past Discuss., https://doi.org/10.5194/cp-2018-29

Manuscript under review for journal Clim. Past

Discussion started: 3 April 2018

(c) Author(s) 2018. CC BY 4.0 License.

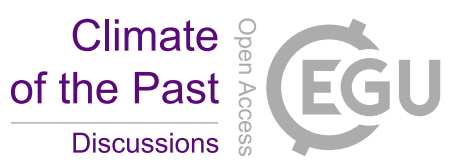

(c) (i)

One interesting result is the small area of evergreen taiga simulated in the south-central land bridge region. Previous simulations from BIOME4 have also produced taiga in the same south-central region (Kaplan et al., 2003). This part of the land bridge is simulated by all models to be relatively warm largely due to the Kuroshio Current, a western boundary current in the Pacific. However, there is no pollen data to suggest evergreen taiga existed here, (yet). While a pollen record from

5 nearby St. Paul Island does not indicate the presence of spruce at the end of the last glaciation ( $\sim 18 \mathrm{k}$ cal BP), willows were certainly present, and possibly birch and alder, though the birch and alder pollen frequencies are $<5 \%$ and could reflect longdistance transport (Wang et al., 2017). In addition, LGM-aged samples from a single marine core off the Bering platform do contain about 3\% spruce pollen and the samples biomise as dwarf shrub tundras, which is not inconsistent with the BIOME4 model results. We need more cores from the southeastern Bering platform to assess whether the consistent modelled presence

10 of taiga is borne out by paleo vegetation data.

\subsubsection{Mid-Holocene}

Simulated biome distributions for the mid-Holocene (Fig 4) vary little from the modern biome reconstruction (Fig 2a). It also has less variability in simulated biomes between models compared to the LGM simulations. Nearly the entire study region is simulated to have shrubby tundras or deciduous taiga or evergreen taiga, except for northern coastal areas. The composite map

15 (Fig 4) shows Alaska largely simulated with evergreen and deciduous taiga and is not so different from the modern reconstruction. The majority of the models put slightly more deciduous taiga in the northern portion of Alaska and western Canada. Biomes simulated in Russia are nearly identical to the modern reconstruction, with deciduous taiga placed in the interior and evergreen taiga along the southern and eastern coast. The simulated vegetation along the Arctic coasts is largely shrubby tundras, with very little cushion-forb tundra simulated. The treeline, as well as boundaries between evergreen and

20 deciduous taiga, and those between tundra and taiga, is simulated in the same location as the modern simulation (Fig 2a). While the warming of the Holocene caused the treeline to shift in some locations around the Arctic, the shift was not uniform around the pole and remained in nearly the same location in the central Beringia region (Bigelow et al., 2003; Kaufman et al., 2004). Deciduous taiga was simulated for approximately the same area percent between models within $\sim 10 \%$, while there is a large range between the coverage of shrubby tundras $(\sim 30 \%)$ and evergreen taiga $(\sim 20 \%)$.

25 Mid-Holocene pollen data indicate that Interior Alaska was dominated by evergreen taiga with the northern and western regions displaying shrubby tundras. This contrasts with BIOME4 which simulates evergreen taiga across a large portion of western Alaska and north of the Brooks Range. Pollen samples in Russia show deciduous taiga in the interior in contrast to the simulation, and pollen of shrubby tundras across the eastern half. A few pollen samples indicate graminoid and forb tundra in the northern reaches of the study region and one sample in the Aleutian Islands. This underscores the issue of indeterminacy in the pollen data. While the climates at the high Arctic and Aleutian sites are very different and the vegetation is different at the species level, the pollen data cannot easily separate between maritime herbaceous tundra from high Arctic herbaceous tundra. 
Clim. Past Discuss., https://doi.org/10.5194/cp-2018-29

Manuscript under review for journal Clim. Past

Discussion started: 3 April 2018

(c) Author(s) 2018. CC BY 4.0 License.

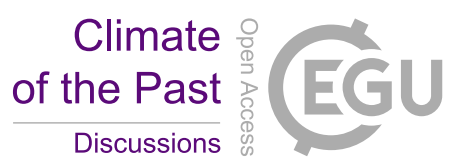

(c) (i)

\subsubsection{Pre-industrial}

The composite map of the simulated pre-industrial biomes (Fig 5a) is generally similar to the simulated modern biome (Fig $2 \mathrm{a}$ ), and the pollen-based reconstruction (Fig $5 \mathrm{~b}$, replicated from Fig $2 \mathrm{~b}$ ). Much of the vegetation simulated for the preindustrial is low and high shrub tundra, erect dwarf shrub tundra, prostrate dwarf shrub tundra, deciduous taiga, and evergreen

5 taiga. All of these biomes exist in the modern reconstruction. More cushion-forb tundra are produced by BIOME4 for this period compared to the modern pollen-based reconstruction. It is worth mentioning that the pre-industrial composite map (Fig 5a) shows that the pre-industrial simulation has the same problem (forested biomes reconstructed in tundra regions of western, northern, and southwest Alaska) as the modern one and for the same reasons as discussed in Sect 3.1.

Pollen samples in Russia show the northern and northeastern coasts dominated by low and high shrub tundra while the interior is dominated by a mixture of low and high shrub tundra and deciduous taiga. A notable discrepancy in Russia is the simulation of evergreen taiga along the southern region of Russia, where the few pollen samples indicate deciduous taiga. Consistent with the over-estimation of forested biomes in the pre-industrial simulation, the pollen map shows cooler biomes (shrubby tundras) in northern, western, and southwestern Alaska

\subsubsection{Future}

15 Future projections of vegetation over the $21^{\text {st }}$ century are simulated based on the averaged climate outputs under the CMIP5 RCP8.5 scenario. The warmer summer temperatures from all the five GCMs increased the GDD 0 index values compared to the modern values across the study region, which translate to BIOME4 simulated reductions in tundra area, increases in evergreen and deciduous taiga area, as well as a northward expansion of warmer biome types from the south (Fig 6). Most of the study region is simulated to have evergreen or deciduous taiga under future climate conditions (about $65-75 \%$ of the region).

20 Tundra type biomes are almost absent in the future simulation but still maintain land coverage in the northern boundaries of the study region. A few small areas along the coast continue to simulate shrubby tundras. One caveat here is, however, that BIOME4 is an equilibrium vegetation model, whereas projected future climate scenarios are transient. Vegetation does not react to climate change as quickly as climate change occurs. One thing to note is the treeline reaching the Arctic coast in the future simulations. This agrees with previous simulations done at an increase of $2^{\circ} \mathrm{C}$ in the Arctic (Kaplan and New, 2006).

25 Future biome projections display less variability and stronger cohesion among the models when compared to the $21 \mathrm{ka}$ and $6 \mathrm{ka}$ simulations. The differences in covering period of the GCM simulations from GISS-E2-R and MPI-ESM (the former for the early part of the century and the latter for the end of the century) did not produce major differences in biome simulations.

\subsection{Sensitivity Analysis}

In order to understand how changes of single climate variables can affect the simulated biome distributions, a series of 30 sensitivity experiments was conducted to evaluate dependencies on temperature $T$ and precipitation amount $P$. Modern values for $T$ and $P$ were changed linearly from the long-term mean monthly climatological values within a prescribed range. For 
Clim. Past Discuss., https://doi.org/10.5194/cp-2018-29

Manuscript under review for journal Clim. Past

Discussion started: 3 April 2018

(c) Author(s) 2018. CC BY 4.0 License.

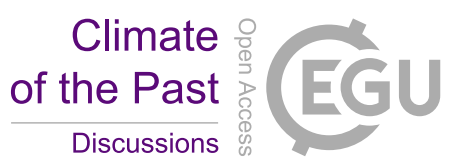

sensitivity on temperature, $T$ was changed by $2^{\circ} \mathrm{C}$ increments from monthly values for a total range of $\pm 10^{\circ} \mathrm{C}$ across all months while $P$ is fixed at the present-day values. In turn, precipitation sensitivity was examined by multiples of $10 \%$ of mean monthly $P$ for a total range of $\pm 150 \%$ across all months.

Resulting simulations show that each biome group appears to have an optimal range of temperature (Fig 7a). Cushion-forb

5 tundra is the most cold-tolerant biome, followed by shrubby tundras, evergreen taiga, deciduous taiga, and cool conifer forest. Warm biome types appear in the region with just $2^{\circ} \mathrm{C}$ warming from the modern climatology. Since the Arctic can be quite dry, it makes sense that as temperatures warm and precipitation is held constant, a desert biome appears in the study region. In reality, precipitation increases as temperature increases in the Arctic (Romanovsky et al., 2017). The modern biome distribution (i.e., the $0^{\circ} \mathrm{C}$ case in Figure 7a) is significantly different from the overall temperature regime trend regarding the percentage 10 of evergreen and deciduous taiga. Compared to the adjacent $\left( \pm 2^{\circ} \mathrm{C}\right)$ regimes, the percentage of evergreen taiga is disproportionally high while that of deciduous taiga is irregularly low. It is known that BIOME4 was optimized for the current Arctic climate (Kaplan et al., 2003), which could explain why incremental changes in temperature produce decidedly different biome distributions from the modern reconstruction. This raises the question of how well can BIOME4 accurately simulate other time periods if it was too strongly optimized for the current climate; however, the simulations for the pre-industrial, midHolocene, and LGM biome distributions show generally good agreement with pollen data.

Arctic biomes simulated by BIOME4 are not as sensitive to precipitation changes (Fig 7b) except, as with the temperature sensitivity experiments, the modern biome distribution with precipitation at $100 \%$ is dominated by evergreen taiga and is very different from the adjacent $90 \%$ and $110 \%$ experiments which are dominated by deciduous taiga. Otherwise, for the range of precipitation change from $50 \%$ to $150 \%$, deciduous taiga coverage decreased by $19 \%$ (from $48.8 \%$ areal occupancy to $39.4 \%$ ) and evergreen taiga increased by $15 \%$ (from $14.4 \%$ areal occupancy to $16.4 \%$ ). All other biomes present in the simulations show very little, if any, sensitivity to increases or decreases in precipitation.

\section{Summary and Conclusions}

Arctic biome distributions simulated by BIOME4 for the modern, pre-industrial, mid-Holocene and Last Glacial Maximum climates were found to be in general agreement with observations, dated paleo-pollen samples, and previous research. The changes in areal occupancy of major biomes under the different Late Quaternary climate conditions were clearly demonstrated (Fig 8). The modern climatology simulation appears to capture the larger picture of our modern-day vegetation distribution. However, through reconstructing the modern biome distribution, we noticed a few regions where BIOME4 does not simulate the proper biome. BIOME4 simulates taiga for north of the Brooks Range and western and southwestern Alaska where shrub type tundra is known to exist. Sensitivity experiments indicate that Arctic biomes are more sensitive to temperature changes than to precipitation. Biomes occupy a range of temperatures but all have an optimal temperature for simulation. Large changes in precipitation were not found to alter the biome distributions. 
Clim. Past Discuss., https://doi.org/10.5194/cp-2018-29

Manuscript under review for journal Clim. Past

Discussion started: 3 April 2018

(c) Author(s) 2018. CC BY 4.0 License.

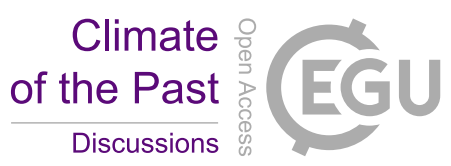

The LGM saw the least amount of agreement among the CMIP5/PMIP3 GCMs. Much of the area is simulated to have cushion-forb tundra, graminoid and forb tundra, or shrubby tundras. A small area in south-central Beringia is simulated to have taiga but the pollen data does not support this. The mid-Holocene simulations were also in good agreement between GCMs. The tree line is in a similar location to modern day, and the entire region is largely taiga. Shrub type tundra is greatly reduced 5 and there is very little cushion-forb tundra.

Simulations for the pre-industrial time period were in general agreement with the tree line simulated slightly south of its present-day position as well as a larger expanse of shrub type tundras. Southwest Alaska is again simulated as evergreen taiga but the pollen data does not support the simulation. Pollen data for the pre-industrial time period shows much more shrub type tundra than is simulated by BIOME4. A steady-state biome distribution corresponding to future warming climate projections

10 shows the Arctic becoming greener with increases in evergreen taiga and deciduous taiga, both of which are simulated to exist at the Arctic coast. All tundra type biomes are greatly reduced in the future, with only a few small areas being projected to still have tundra. Warmer biomes begin to migrate much farther than previous climates have allowed. Future biome projections show very good agreement between CMIP5 models, indicating high confidence in the climate projections for the $21^{\text {st }}$ century under IPCC's RCP 8.5 scenario, subject to the caveat that BIOME4 is an equilibrium model. The projections agree with previous simulations conducted for another warmer climate scenario.

The results presented in this thesis have potential to be used in future research projects looking at climate-vegetationpermafrost dynamics. Future work could include translating simulated biome distributions to soil organic layer depth for the use in subsurface models that simulate changes in permafrost and hydrology. The biome distributions could also be used to explore how changes in land-surface dynamics will impact climate through changes in evapotranspiration, albedo, and carbon exchanges.

\section{Data accessibility}

The simulated data and pollen data analysed in this paper, together with the attributional information, are archived and accessible at the International Arctic Research Center Data Archive of the University of Alaska Fairbanks (http://climate.iarc.uaf.edu/geonetwork/srv/en/main.home?uuid=ab8b5098-2df8-47bb-9006-e28fcf4da866 and http://climate.iarc.uaf.edu/geonetwork/srv/en/main.home?uuid=8767086f-4b04-4b7b-99f1-de108a9c24d3).

\section{Author contribution}

KS designed the experiments with advices and discussions with NB and JW. AH developed the model code and performed the simulations. All authors carried the project out. AH wrote the original manuscript as her master's thesis, and KS prepared the manuscript with contributions from all co-authors. 
Clim. Past Discuss., https://doi.org/10.5194/cp-2018-29

Manuscript under review for journal Clim. Past

Discussion started: 3 April 2018

(c) Author(s) 2018. CC BY 4.0 License.

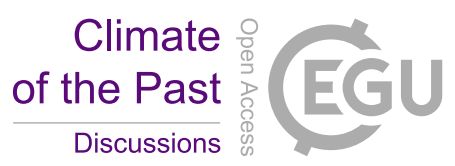

(c) (i)

\section{Acknowledgments}

This study was partially supported by the U.S. National Science Foundation ARC-1107524; Environment Research and Technology Development Fund (2-1605), the Ministry of the Environment and Environmental Restoration and Conservation Agency, Japan; and by the Program for Risk Information on Climate Change (SOUSEI Program), the Integrated Research

5 Program for Advancing Climate Models (TOUGOU program), and the Arctic Challenge for Sustainability (ArCS) program, all of the Ministry of Education, Culture, Sports, Science, and Technology, Japan. Authors are thankful for the insightful advices and discussions in conducting the study with Profs. S. Marchenko, K. Yoshikawa, and V. Romanovsky, Dr. B. OttoBliesner and Dr. J. Kaplan. Heather Binney provided additional pollen data and computer code for the pollen biomization.

\section{References}

Abbott, M. B., Edwards, M. E., and Finney, B. P.: A 40,000-yr record of environmental change from Burial Lake in Northwest Alaska. Quaternary Research 74, 156-165, 10.1016/j.yqres.2010.03.007, 2010.

ACIA: Impacts of a Warming Arctic: Arctic Climate Impact Assessment. Cambridge University Press, Cambridge, 139 pp, 2005.

Ager, T. A., and Phillips, R. L.: Pollen evidence for late Pleistocene Bering Land Bridge environments for Norton Sound, northeastern Bering Sea, Alaska. Arctic, Antarctic, and Alpine Research 40, 451-461, 2008.

Anderson, P. M., Edwards, M. E., and Brubaker, L. B.: Results and paleoclimate implications of 35 years of paleoecological research in Alaska. In "The Quaternary Period in the United States." (A. R. Gillespie, and S. C. Porter, Eds.), pp. 427440. Elsevier, Amsterdam, 2004.

Bartlein, P. J., Edwards, M.E., Hostetler, S.W., Shafer, S.L., Anderson, P.M., Brubaker, L.B. and Lozhkin, A.V.: EarlyHolocene warming in Beringia and its mediation by sea-level and vegetation changes. Clim. Past, 11, 873-932, 2015.

Bartlein, P. J., Harrison, S. P., Brewer, S., Connor, S., Davis, B. A. S., Gajewski, K., Guiot, J., Harrison-Prentice, T. I., Henderson, A., Peyron, O., Prentice, I. C., Scholze, M., Seppa, H., Shuman, B., Sugita, S., Thompson, R. S., Viau, A. E., Williams, J., and Wu, H.: Pollen-based continental climate reconstructions at 6 and 21 ka: a global synthesis. Climate Dynamics 37, 775-802, http://dx.doi.org/10.1007/s00382-010-0904-1, 2011.

Bieniek, P.A., Bhatt, U.S., Thoman, R.L., Angeloff, H., Partain, J., Papineau, J., Frisch, F., Hollowar, E., Walsh, J.E., Daly, C., Shulski, M., Hufford, G., Hill, D.F., Calos, S., and Gens, R.: Climate Divisions for Alaska Based on Objective Methods. J. Appl. Met. and Clim., 51, doi:10.1175/JAMC-D-11-0168.1., 2012.

Bigelow, N. H.. Pollen records, Late Pleistocene | Northern North America. In "Encyclopedia of Quaternary Science (Second Edition)." (S. A. Elias, and C. J. Mock, Eds.), pp. 39-51. Elsevier, Amsterdam, 2013.

Bigelow, N.H., Brubaker, L.B., Edwards, M.E., Harrison, S.P., Prentice, I.C., Anderson, P.M., Andreev, A.A,. Bartlein, P.J., Christensen, T.R., Cramer, W., Kaplan, J.O., Lozhkin, A.V., Matveyeva, N.V., Murray, D.F., McGuire, A.D., 
Clim. Past Discuss., https://doi.org/10.5194/cp-2018-29

Manuscript under review for journal Clim. Past

Discussion started: 3 April 2018

(c) Author(s) 2018. CC BY 4.0 License.

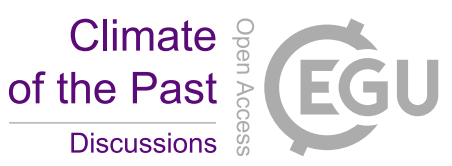

Razzhivin, V.Y., Ritchie, J.C., Smith, B., Walker, D.A., Gajewski, K., Wolf, V., Holmqvist, B.H., Igarashi, Y., Kremenetskii, K., Paus, A., Pisaric, M.F.J., and Volkova, V.S.: Climate change and Arctic ecosystems: 1. Vegetation changes north of $55^{\circ} \mathrm{N}$ between the last glacial maximum, mid-Holocene, and present. J. Geophys. Res., 108, doi: 10.1029/2002D002558, 2003.

5 Boggs, K., Boucher, T.V. and Kuo, T.: Vegetation Map and Classification: Southern Alaska and Aleutian Islands. Alaska Natural Heritage Program, University of Alaska Anchorage, Anchorage. http://aknhp.uaa.alaska.edu, 2014a.

Boggs, K., Boucher, T.V., and Kuo, T.: Vegetation Map and Classification: Northern, Western and Interior Alaska. Alaska Natural Heritage Program, University of Alaska Anchorage, Anchorage. http://aknhp.uaa.alaska.edu, 2014b.

Braconnot, P., Harrison, S.P., Kageyama, M., Bartlein, P.J., Masson - Delmotte, V., Abe-Ouchi, A., Otto-Bliesner, B., and

Zhao, Y.: Evaluation of climate models using palaeoclimatic data. Nat. Clim. Chan. 2, 417-424, 2012.

Briner, J. P., and Kaufman, D. S.: Late Pleistocene mountain glaciation in Alaska: key chronologies. J. Quaternary Sci 23, 659-670, doi:10.10,02/jqs.1196, 2008.

Brovkin, V., Boysen, L., Raddatz, T., Gayler, V., Loew, A., and Claussen, M.: Evaluation of vegetation cover and landsurface albedo in MPI-ESM CMIP5 simulations. J. Adv. Model. Earth Syst., 5, 48-57, doi:10.1029/2012MS000169, 2013.

15 Callaghan, T. V., Johansson, M., Anisimov, O., Christiansen, H. H., Instanes, A., Romanovsky, V., and Smith, S.: Changing permafrost and its impacts. In: Snow, Water, Ice and Permafrost in the Arctic (SWIPA): Climate Change and the Cryosphere. pp. [5-1 - 5-62]. Arctic Monitoring and Assessment Programme (AMAP), Oslo, Norway, 2011.

Cannonne, N, Ellis Evans, J.C., Strachan, R., and Guglielmin, M.: Interactions between climate, vegetation and the active layer in soils at two Maritime Antarctic sites. Antarc. Sci., 18, 323-333. DOI 10.1017/S095410200600037X, 2006.

CAVM Team.: Circumpolar Arctic Vegetation Map. In "Conservation of Arctic Flora and Fauna Map No. 1." (D. A. Walker, Ed.). U.S. Fish and Wildlife Service, Anchorage, 2003.

Chapin III, F.S., Jefferies, R.L., Reynolds, J.F., Shaver, G. R., and Svoboda, J. (eds.): Arctic ecosystems in a changing climate: an ecophysiological perspective, Academic Press, San Diego, pp. 469, 1992.

Chapin III, F.S. and Körner, C. (eds.): Arctic and alipine biodiversity: patterns, causes, and ecosystem consequences. Ecological studies 113, Springer-Verlag, Berlin Heidelberg, pp. 332, 1995.

Clark, P. U. and Mix, A. C.: Ice sheets and sea level of the Last Glacial Maximum. Quaternary Science Reviews 21, 1-7, 2002. Ehlers, J., Gibbard, P. L., and Hughes, P. D.: Quaternary Glaciations--Extent and Chronology: A closer look. Elsevier, Amsteram, 2011

Elias, S. A., and Crocker, B.: The Bering Land Bridge: a moisture barrier to the dispersal of steppe-tundra biota? Quaternary Science Reviews 27, 2473-2483, 10.1016/j.quascirev.2008.09.011, 2008.

Elias, S. A., Short, S. K., and Birks, H. H.: Late Wisconsin environments of the Bering Land Bridge. Palaeogeography, Palaeoclimatology, Palaeoecology 136, 293-308, 10.1016/s0031-0182(97)00038-2, 1997.

French, H. M.: The periglacial environment 3rd Edn.,Wiley, Chichester, 2007. 
Clim. Past Discuss., https://doi.org/10.5194/cp-2018-29

Manuscript under review for journal Clim. Past

Discussion started: 3 April 2018

(c) Author(s) 2018. CC BY 4.0 License.

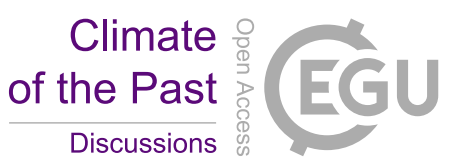

Frenzel, B., Pécsi, M., and Velichko, A. A. (Eds.): Atlas of Paleoclimates and Paleoenvironments of the Northern Hemisphere, Geographical Research Institute, Hungarian Academy of Sciences, Budapest, 153 pp., Gustav Fischer Verlag, Stuttgart, 1992.

Garsia, M.G., ed: The Forests of the USSR: Map Scale 1:2500000, prepared by the department of the forest cartography of Souzgiprosleskhoza. Moscow: GUGK, 1990.

Gent, P.R., Danabasoglu, G., Donner, L.J., Holland, M.M., Hunke, E.C., Jayne, S.R., Lawrence, D.M., Neale, R.B., Rasch, P.J., Vertenstein, M., Worley, P.H., Yang, Z., and Zhang, M.: The Community Climate System Model Version 4. J. Clim. 24, 4973-4991, 2011.

Haxeltine, A., and Prentice, I.C.: BIOME3: An equilibrium terrestrial biosphere model based on ecophysiological constraints, resource availability, and competition among plant functional types. Glob. Biogeochem. Cyc. 10, 693-709, 1996.

Hopkins, D. M. (1982). Aspects of the paleogeography of Beringia during the late Pleistocene. In "Paleoecology of Beringia." (D. M. Hopkins, J. J. V. Matthews, C. E. Schweger, and S. B. Young, Eds.), pp. 3-28. Academic Press, New York, 1996.

Hopkins, D.M., Matthews, J.V., and Schweger, C.E. (eds.): Paleoecology of Beringia. Academic Press, New York, NY, 504 pp., 1982

IPCC: Climate Change 2013: The Physical Science Basis. Contribution of Working Group I to the Fifth Assessment Report of the Intergovernmental Panel on Climate Change. Cambridge University Press, Cambridge, United Kingdom and New York, NY, USA, 2013.

Kaplan, J.O. and New, M.: Arctic climate change with a $2^{\circ} \mathrm{C}$ global warming: Timing, climate patterns, and vegetation change. J. Clim. Change 79, 213-241, 2006.

Kaplan, J.O., Bigelow, N.H., Prentice, I.C., Harrison, S.P., Bartlein, P.J., Christensen, T.R., Cramer, W., Matveyeva, N.V., McGuire, A.D., Murray, D.F., Razzhivin, V.Y., Smith, B., Walker, D.A., Anderson, P.M., Andreev, A.A., Brubaker, L.B., Edwards, M.E., and Lozhkin, A.V.: Climate change and Arctic ecosystems: 2. Modeling, paleo-model comparisons, and future projections. J. Geophys. Res. 108, doi: 10.1029/2002D002559, 2003.

Kaufman, D. S., Ager, T. A., Anderson, N. J., Anderson, P. M., Andrews, J. T., Bartlein, P. J., Brubaker, L. B., Coats, L. L., Cwynar, L. C., Duvall, M. L., Dyke, A. S., Edwards, M. E., Eisner, W. R., Gajewski, K., Geirsdóttir, A., Hu, F. S., Jennings, A. E., Kaplan, M. R., Kerwin, M. W., Lozhkin, A. V., MacDonald, G. M., Miller, G. H., Mock, C. J., Oswald, W. W., Otto-Bleisner, B. L., Porinchu, D. F., Rühland, K., Smol, J. P., Steig, E. J., and Wolfe, B. B.: Holocene thermal maximum in the western Arctic (0-180 $\left.{ }^{\circ} \mathrm{W}\right)$. Quaternary Science Reviews 23, 529-560, 2004.

Kurek, J., Cwynar, L. C., Ager, T. A., Abbott, M. B., and Edwards, M. E.: Late Quaternary paleoclimate of western Alaska inferred from fossil chironomids and its relation to vegetation histories. Quaternary Science Reviews 28, 799-811, 10.1016/j.quascirev.2008.12.001, 2009.

Lozhkin, A. V., and Anderson, P. M.: Pollen Records, Late Pleistocene| Northern Asia. In "Encyclopedia of Quaternary Science." (S. A. Elias, Ed.), pp. 2623-2633. Elsevier, Amsterdam, 2007. 
Clim. Past Discuss., https://doi.org/10.5194/cp-2018-29

Manuscript under review for journal Clim. Past

Discussion started: 3 April 2018

(c) Author(s) 2018. CC BY 4.0 License.

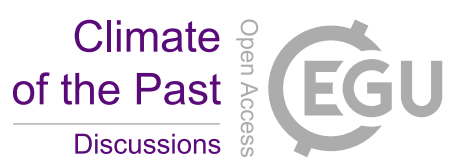

Matsuura, K. and Willmott, C.J.: Terrestrial Air Temperature: 1900-2008 Gridded Monthly Time Series (Version 2.01). Center for Climatic Research, University of Delaware, 2009a.

Matsuura, K. and Willmott, C.J.: Terrestrial Precipitation: 1900-2008 Gridded Monthly Time Series (Version 2.01). Center for Climatic Research, University of Delaware, 2009b.

5 Milne, G. A. \& Mitrovica, J. X.: Searching for eustasy in deglacial sea-level histories. Quaternary Science Reviews 27, 2292 2302, 2008.

Muhs, D. R., Ager, T. A., Been, J., Bradbury, J. P., and Dean, W. E.: A late quaternary record of eolian silt deposition in a maar lake, St. Michael Island, western Alaska. Quaternary Research 60, 110-122, http://dx.doi.org/10.1016/S00335894(03)00062-0, 2003.

NSIDC, 2015: All About Frozen Ground. Accessed May 2015. [Available online at https://nsidc.org/cryosphere/frozenground/index.html.]

Prentice, I. C., and Webb III, T.: BIOME 6000: reconstructing global mid-Holocene vegetation patterns from palaeoecological records. Journal of Biogeography 25, 997-1005, 1998.

Prentice, I. C., Guiot, J., Huntley, B., Jolly, D., and Cheddadi, R.: Reconstructing biomes from palaeoecological data: A general method and its application to European pollen data at 0 and 6 ka. Climate Dynamics 12, 185-194, 1996.

Renssen, H., Seppä, H., Crosta, X., Goosse, H., and Roche, D. M.: Global characterization of the Holocene Thermal Maximum. Quaternary Science Reviews 48, 7-19, doi:10.1016/j.quascirev.2012.05.022, 2012.

Romanovsky, V., Isaksen, K., Drozdov, D., Anisimov, O., Instanes, A., Leibman, M., McGuire, A. D., Shiklomanov, N., Smith, S., Walker, S.: Changing permafrost and its impacts. In: Snow, Water, Ice and Permafrost in the Arctic (SWIPA) 2017. pp. 65-102. Arctic Monitoring and Assessment Programme (AMAP), Oslo, Norway, 2017.

Saito, K., Zhang, T., Yang, D., Marchenko, S., Barry, R. G., Romanovsky, V., and Hinzman, L.: Influence of the Physical Terrestrial Arctic in the Eco-climate System, Ecological Applications 23(8), 1778-1797, doi:10.1890/11-1062.1, 2013a.

Saito, K., Sueyoshi, T., Marchenko, S., Romanovsky, V., Otto-Bliesner, B., Walsh, J., Bigelow, N., Hendricks, A., Yoshikawa, K.: LGM permafrost distribution: How well can the latest PMIP multi-model ensembles perform reconstruction? Climate of the Past 9, 1697-1714. doi:10.5194/cp-9-1697-2013, 2013b.

Schmidt, G.A., Kelley, M., Nazarenko, L., Ruedy, R., Russell, G.L., Aleinov, I., Bauer, M., Bauer, S.E., Bhat, M.K., Bleck, R. Canuto, V., Chen, Y.-H., Cheng, Y., Clune, T.L., Del Genio, A., de Fainchtein, R., Faluvegi, G., Hansen, J.E., Healy, R.J., Kiang, N.Y., Koch, D., Lacis, A.A., LeGrande, A.N., Lerner, J., Lo, K.K., Matthews, E.E., Menon, S., Miller, R.L., Oinas, V., Oloso, A.O., Perlwitz, J.P., Puma, M.J., Putman, W.M., Rind, D., Romanou, A., Sato, M., Shindell, D.T., Sun, S., Syed, R.A., Tausnev, N., Tsigaridis, K., Unger, N., Voulgarakis, A., Yao, M.-S., and Zhang, J.: Configuration and assessment of the GISS ModelE2 contributions to the CMIP5 archive. J. Adv. Model. Earth Syst., 6, no. 1, 141-184, doi:10.1002/2013MS000265, 2014.

Serreze, M.C. and Barry, R.G.: The Arctic climate system. Cambridge University Press, New York, NY, 415 pp, 2014. 
Clim. Past Discuss., https://doi.org/10.5194/cp-2018-29

Manuscript under review for journal Clim. Past

Discussion started: 3 April 2018

(c) Author(s) 2018. CC BY 4.0 License.

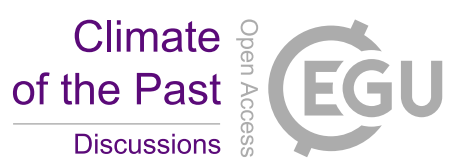

Shur, Y.L and Jorgenson, M.T.: Patterns of Permafrost Formation and Degradation in Relation to Climate and Ecosystems. Permafr. and Perigl. Proc., 18, 7-18, 2007.

Taylor, K.E., Meehl, G.A. and Stouffer, R.J.: An Overview of CMIP5 and the Experimental Design. Boul. Amer. Met. Soc., 93, 485-498, 2012.

5 Uppala, S.M., KAllberg, P.W., Simmons, A.J., Andrae, U., Da Costa Bechtold, V., Fiorino, M., Gibson, J.K., Haseler, J., Hernandez, A., Kelly, G.A., Li, X., Onogi, K., Saarinen, S., Sokka, N., Allan, R.P., Andersson, E., Arpe, K., Balmaseda, M.A., Beljaars, A.C.M., Van De Berg, L., Bidlot, J., Bormann, N,, Caires, S., Chevallier, F., Dethof, A., Dragosavac, M., Fisher, M., Fuentes, M., Hagemann, S., Holm, E., Hoskins, B.J., Isaksen, L., Janssen, P. A. E. M., Jenne, R., Mcnally, A. P., Mahfouf, J.-F., Morcrette, J.-J., Rayner, N. A., Saunders, R. W., Simon, P., Sterl, A., Trenberth, K. E., Untch, A., Vasiljevic, D., Viterbo, P., and Woollen, J.: The ERA-40 re-analysis. Q.J.R. Met. Soc., 131, 2961-3012, 2005.

Van Everdingen, R. (ed.): Multi-Language Glossary of Permafrost and Related Ground-Ice Terms, revised May 2005. National Snow and Ice Data Center/World Data Center for Glaciology, Boulder, CO, http://nsidc.org/fgdc/glossary/, 1998.

Viau, A. E., Gajewski, K., Sawada, M. C., and Bunbury, J.: Low- and high-frequency climate variability in eastern Beringia during the past 25000 years. Canadian Journal of Earth Sciences = Revue Canadienne des Sciences de la Terre $\mathbf{4 5}$, 1435-1453, 2008.

Viereck, L.A., and Little, E.L.: Alaska Trees and Shrubs. Department of Agriculture, Washington D.C., 265 pp, 1972.

Walker, D. A., Jia, G. J., Epstein, H. E., Raynolds, M. K., Chapin III, F. S., Copass, C., Hinzman, L. D., Knudson, J.A., Maier, H.A., Michaelson, G.J., Nelson, F., Ping, C.L., Romanovsky, V.E., and Shiklomanov, N.: Vegetation-soil-thaw-depth relationships along a low-arctic bioclimate gradient, Alaska: Synthesis of information from the ATLAS studies. Permafr. and Perigl. Proc. 14,103-123, 2003.

Wang, Y., Heintzman, P. D., Newsom, L., Bigelow, N. H., Wooller, M. J., Shapiro, B., and Williams, J. W.: The southern coastal Beringian land bridge: cryptic refugium or pseudorefugium for woody plants during the Last Glacial Maximum? Journal of Biogeography, doi:10.1111/jbi.13010, 2017.

Watanabe, S., Hajima, T., Sudo, K., Nagashima, T., Takemura, T., Okajima, H., Nozawa, T., Kawase, H., Abe, M., Yokohata, T., and Ise, T.: MIROC-ESM 2010: model description and basic results of CMIP 5-20 c 3 m experiments. Geosci. Mod. Dev, 4, 845-872, 2011.

Wolf, V. G.: A Window to the Past: Macrofossil Remains from an 18,000 Year-Old Buried Surface, Seward Peninsula, Alaska. Unpublished MS thesis, University of Alaska Fairbanks, 2001.

Yukimoto, S., Adachi, Y., Hosaka, M., Sakami, T., Yoshimura, H., Hirabara, M., Tanaka, T. Y., Shindo, E., Tsujino, H., Deushi, M., and Mizuta, R.: A new global climate model of the Meteorological Research Institute: MRI-CGCM3model description and basic performance. Journ. Met. Soc. Japan, 90A, 23-64, 2012.

Zhang, T., Barry, R. G., Knowles, K., Heginbottom, J. A., and Brown, J.: Statistics and characteristics of permafrost and ground ice distribution in the Northern Hemisphere. Polar Geography 23(2), 147-169, 1999. 
Clim. Past Discuss., https://doi.org/10.5194/cp-2018-29

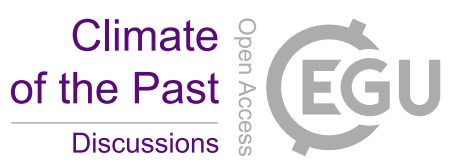

Discussion started: 3 April 2018

(c) Author(s) 2018. CC BY 4.0 License.

(c) (i)

Table 1. Simulation lengths and horizontal resolutions (degrees latitude $\times$ degrees longitude) for CMIP5/PMIP3 climate data.

\begin{tabular}{|c|c|c|c|c|c|}
\hline & $\begin{array}{l}\text { CCSM4 } \\
1.06^{\circ} \times 1.25^{\circ}\end{array}$ & $\begin{array}{l}\text { GISS-E2-R } \\
2^{\circ} \times 2.5^{\circ}\end{array}$ & $\begin{array}{l}\text { MIROC-ESM } \\
2.8125^{\circ} \times 2.8125^{\circ}\end{array}$ & $\begin{array}{l}\text { MPI-ESM } \\
1.875^{\circ} \times 1.875^{\circ}\end{array}$ & $\begin{array}{l}\text { MRI-CGCM3 } \\
1.125^{\circ} \times 1.125^{\circ}\end{array}$ \\
\hline LGM & 101 years & 25 years & 100 years & 100 years & 100 years \\
\hline Mid-Holocene & 301 years & 25 years & 100 years & 100 years & 100 years \\
\hline Pre-industrial & 251 years & 25 years & 99 years & 200 years & 500 years \\
\hline Future RCP 8.5 & $2006-2100$ & $2006-2025$ & $2006-2100$ & $2070-2100$ & $2006-2100$ \\
\hline $\begin{array}{l}\text { Modern } \\
\text { (historical) }\end{array}$ & $1979-2010$ & $1910-1950$ & 1979-2006 & $1979-2008$ & $1979-2010$ \\
\hline References & $\begin{array}{l}\text { Gent et al., } \\
2011\end{array}$ & $\begin{array}{l}\text { Schmidt et al., } \\
2014\end{array}$ & $\begin{array}{l}\text { Watanabe et al., } \\
2011\end{array}$ & Brovkin et al., 2013 & $\begin{array}{l}\text { Yukimoto et al., } \\
2012\end{array}$ \\
\hline
\end{tabular}


Clim. Past Discuss., https://doi.org/10.5194/cp-2018-29

Climate

Manuscript under review for journal Clim. Past

Discussion started: 3 April 2018

(c) Author(s) 2018. CC BY 4.0 License.

Table 2. Comparison of biome names used in this study and the homogenized nomenclature (BIOME 6000)

\begin{tabular}{|c|c|c|}
\hline Biome names used in the text & $\begin{array}{l}\text { Homogenized biome names (BIOME } \\
\qquad 6000)^{\mathrm{a}}\end{array}$ & BIOME4 names (Kaplan et al. 2003) \\
\hline Ocean & Ocean & Ocean \\
\hline Ice & Ice & Ice \\
\hline Barren & Barren & Barren \\
\hline Cushion-forb tundra & Cushion-forb tundra & Cushion forbs, lichen, and moss \\
\hline Prostrate dwarf shrub tundra & Prostrate dwarf shrub tundra & Prostrate dwarf shrub tundra \\
\hline Erect dwarf shrub tundra & Erect dwarf shrub tundra & Erect dwarf shrub tundra \\
\hline Low and high shrub tundra & Low and high shrub tundra & Low and high shrub tundra \\
\hline Graminoid and forb tundra & Graminoid and forb tundra & Graminoid and forb tundra \\
\hline Deciduous taiga & Cold deciduous forest & Deciduous taiga/montaine forest \\
\hline Evergreen taiga & Cold evergreen needeleaf forest & Evergreen taiga/montane forest \\
\hline Cool mixed forest & Cool mixed forest & Cool mixed forest \\
\hline Cool conifer forest & Cool evergreen needleleaf forest & Cool conifer forest \\
\hline Cool-temperate mixed forest & $\begin{array}{l}\text { Cool-temperate evergreen needle leaf \& } \\
\text { mixed forest }\end{array}$ & Cold mixed forest \\
\hline Temperate conifer forest & Temperate evergreen needleleaf forest & Temperate conifer forest \\
\hline Warm-temperate mixed forest & $\begin{array}{l}\text { Warm-temperate evergreen broadleaf and } \\
\text { mixed forest }\end{array}$ & Warm mixed forest \\
\hline \multirow{2}{*}{$\begin{array}{l}\text { Temperate } \\
\text { woodland }\end{array}$} & Temperate xerophytic shrubland & Temperate xerophytic shrubland \\
\hline & $\begin{array}{l}\text { Temperate sclerophyll woodland and } \\
\text { shrubland }\end{array}$ & Temperate sclerophyll woodland \\
\hline Temperate grassland & Temperate grassland & Temperate grassland \\
\hline Desert & Desert & Desert \\
\hline
\end{tabular}

a: http://www.bridge.bris.ac.uk/resources/Databases/BIOMES_data. Accessed March 22, 2018. 
Clim. Past Discuss., https://doi.org/10.5194/cp-2018-29

Manuscript under review for journal Clim. Past

Discussion started: 3 April 2018

(c) Author(s) 2018. CC BY 4.0 License.

Figure captions:

Figure 1: Domain of the study. Modern and LGM coastlines, together with LGM land ice (ice sheets) extent.

Figure 2: (a) Modern distribution of biomes simulated by BIOME4 with observational forcing described in Section 2.2. (b). Modern biomes from pollen analysis.

5 Figure 3: LGM biome reconstructions. a) Model composite, b) pollen results, c) - g) each GCM outputs.

Figure 4: Mid-Holocene (Holocene Optimum result, 6ka) reconstruction. a) Model composite, b) pollen results

Figure 5: Pre-industrial reconstruction. a) Model composite, b) pollen results (replicate of Fig 2b)

Figure 6: $21^{\text {st }}$ century result under RCP 8.5 scenario.

Figure 7: Sensitivity results for a) temperature and b) precipitation amount. Biomes are grouped to Cushion-forb

10 tundra, Tundras (Prostate dwarf shrub tundra; Erect dwarf shrub tundra; Low and high shrub tundra; Graminoid and forb tundra), Deciduous taiga, Evergreen taiga, Cool evergreen (Cool-temperate mixed forest; cool conifer forest), Warm/cool mixed (Cool mixed forest; Warm-temperate mixed forest), Tmprt grassland (Temperate grassland), Tmprt shrub/woodland (Temperate shrubland or woodland), Tmprt forest (Temperate conifer forest, Temperate deciduous forest), Desert (Desert), and Barren (Barren).

15 Figure 8: Summarizing figure to show the transition of vegetation/biomes in Beringia in the 20 thousand years. Same biome grouping as in Fig 7, except that desert is omitted, and temperate biomes are grouped together for brevity. 
Clim. Past Discuss., https://doi.org/10.5194/cp-2018-29

Manuscript under review for journal Clim. Past

Discussion started: 3 April 2018

(c) Author(s) 2018. CC BY 4.0 License.

\section{Climate of the Past \\ Discussions}

(c) (i)

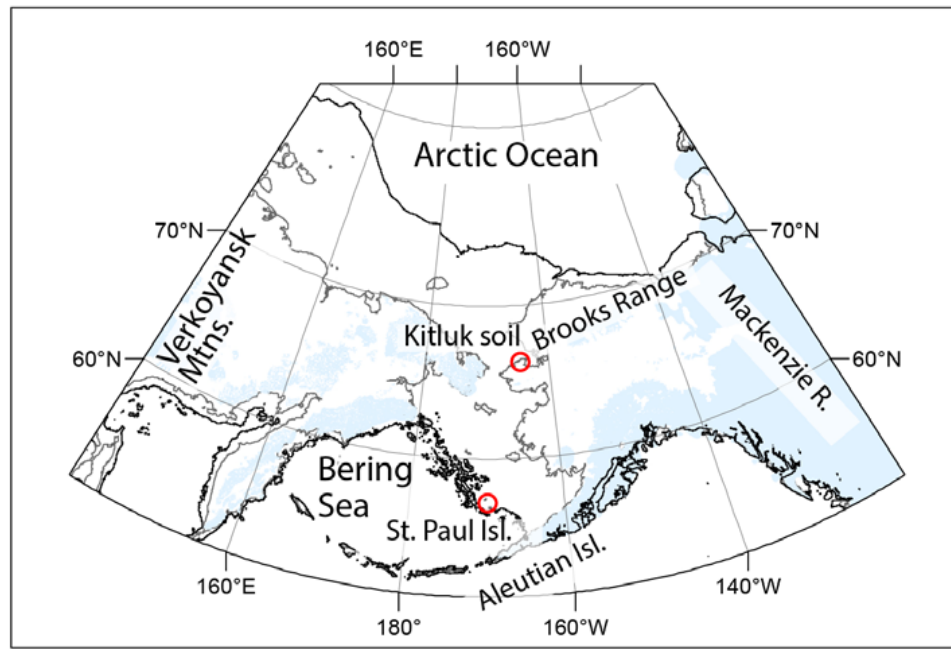

$-120 \mathrm{~m}$ shoreline

LGM ice extent

fig01 
Clim. Past Discuss., https://doi.org/10.5194/cp-2018-29

Manuscript under review for journal Clim. Past

Discussion started: 3 April 2018

(c) Author(s) 2018. CC BY 4.0 License.

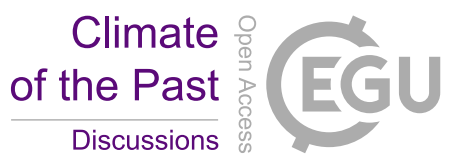

(c) (1)
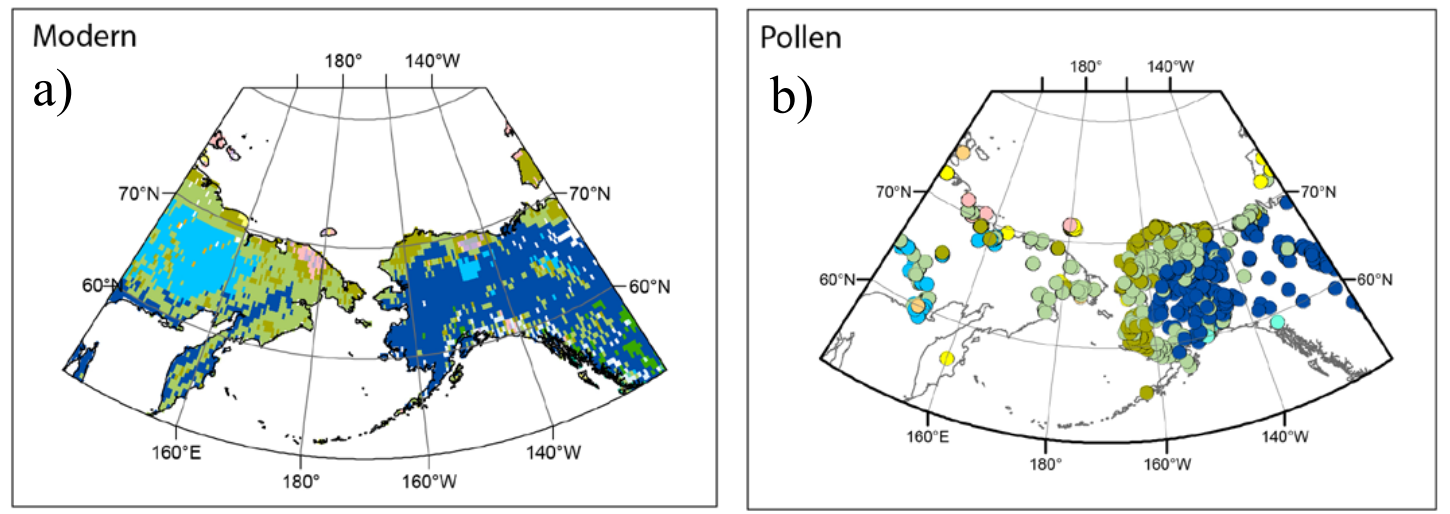

Modern

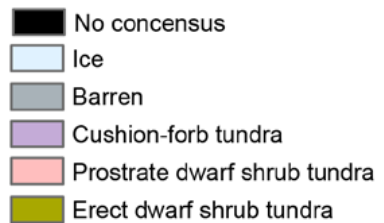

$\square$ Low and high shrub tundra
$\square$ Graminoid and forb tundra
Deciduous taiga
Evergreen taiga
$\square$ Cool mixed forest
Cool conifer forest

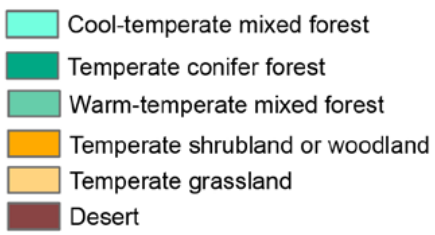

fig02 
Clim. Past Discuss., https://doi.org/10.5194/cp-2018-29

Manuscript under review for journal Clim. Past

Discussion started: 3 April 2018

(C) Author(s) 2018. CC BY 4.0 License.
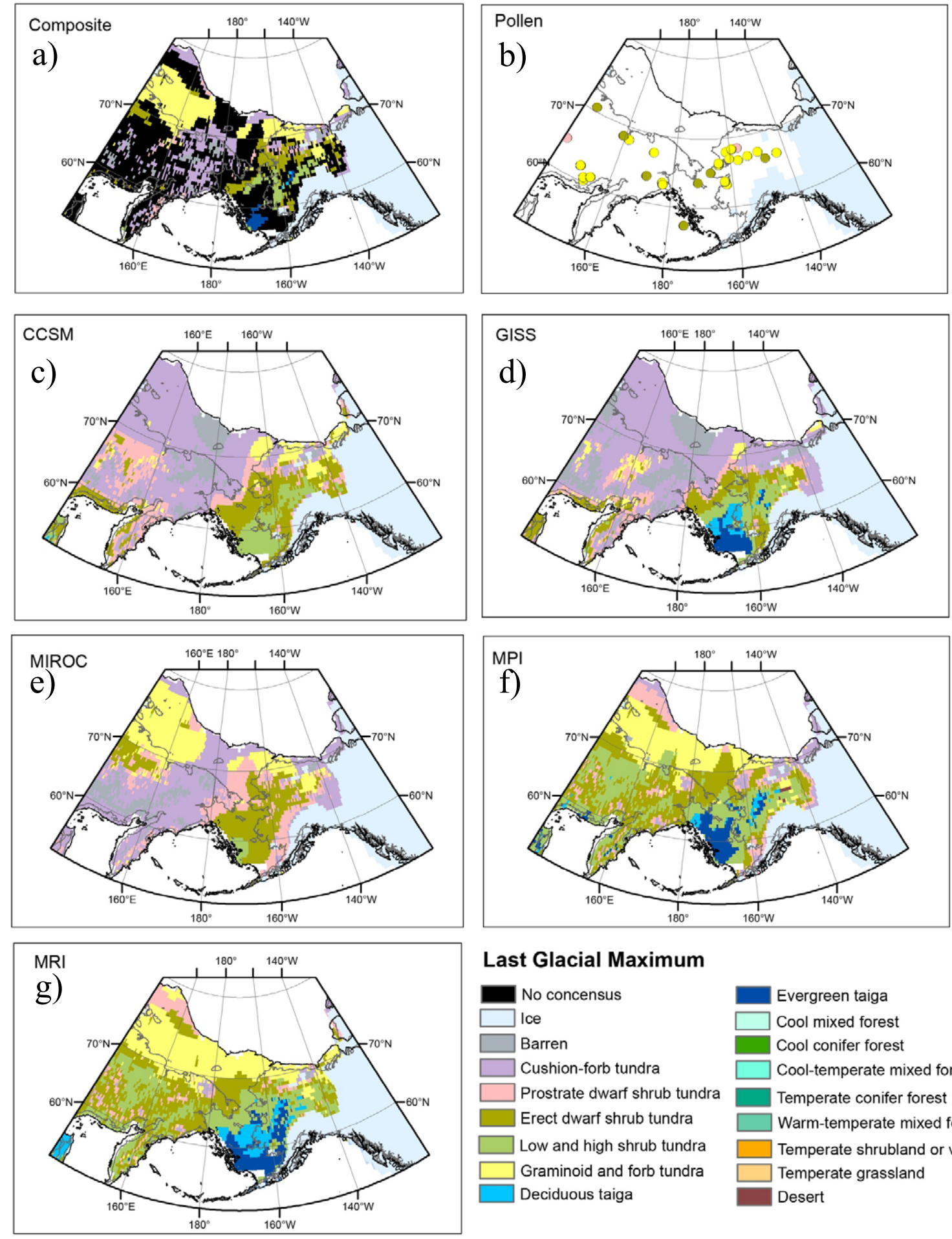

\section{Last Glacial Maximum}

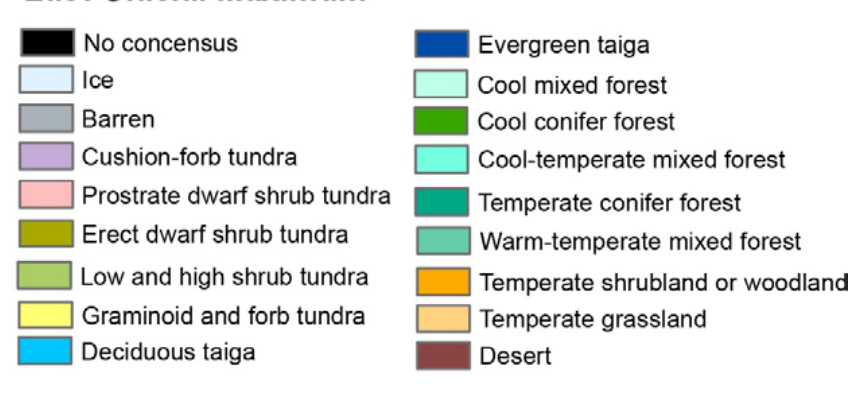


Clim. Past Discuss., https://doi.org/10.5194/cp-2018-29

Manuscript under review for journal Clim. Past

Discussion started: 3 April 2018

(c) Author(s) 2018. CC BY 4.0 License.

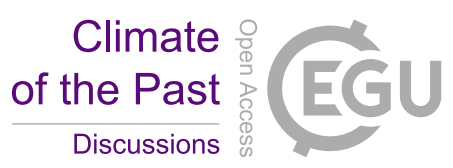

(c) (1)
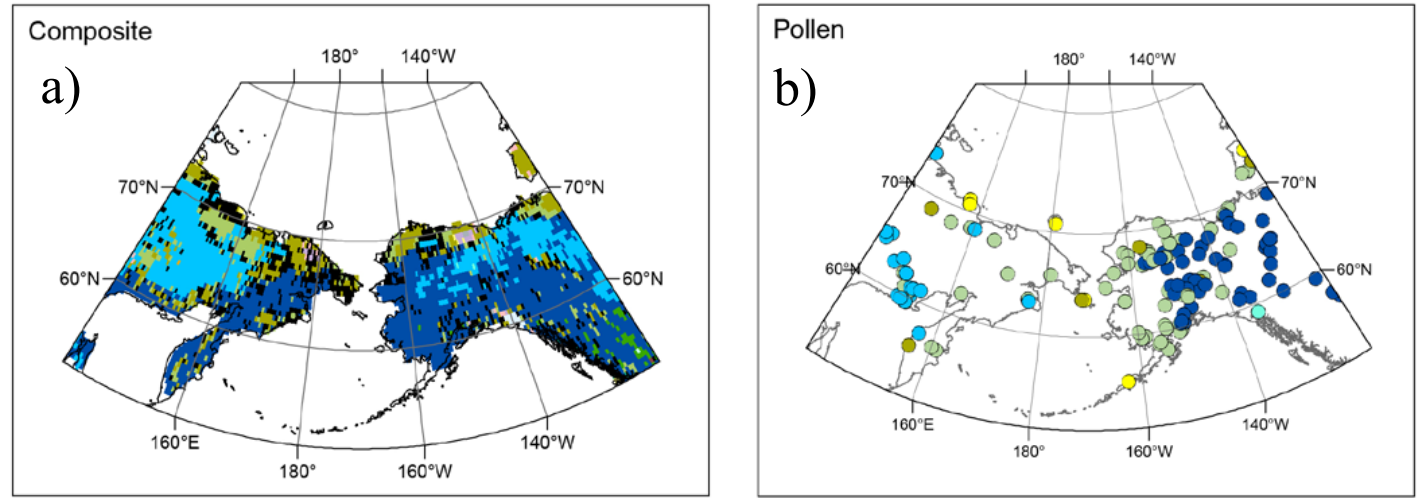

Mid-Holocene

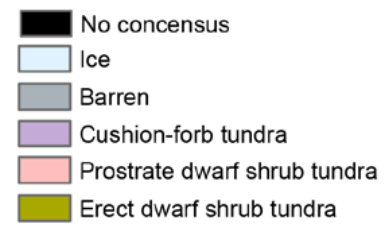

Low and high shrub tundra

Cool-temperate mixed forest

$\square$ Graminoid and forb tundra

Deciduous taiga

Evergreen taiga

Cool mixed forest

Cool conifer forest

Temperate conifer forest

Warm-temperate mixed forest

Temperate shrubland or woodland

Temperate grassland

Desert

fig04 
Clim. Past Discuss., https://doi.org/10.5194/cp-2018-29

Manuscript under review for journal Clim. Past

Discussion started: 3 April 2018

(c) Author(s) 2018. CC BY 4.0 License.

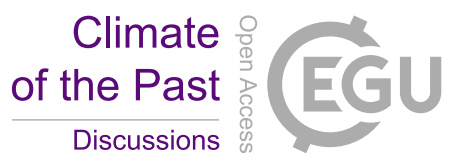

(c) (i)
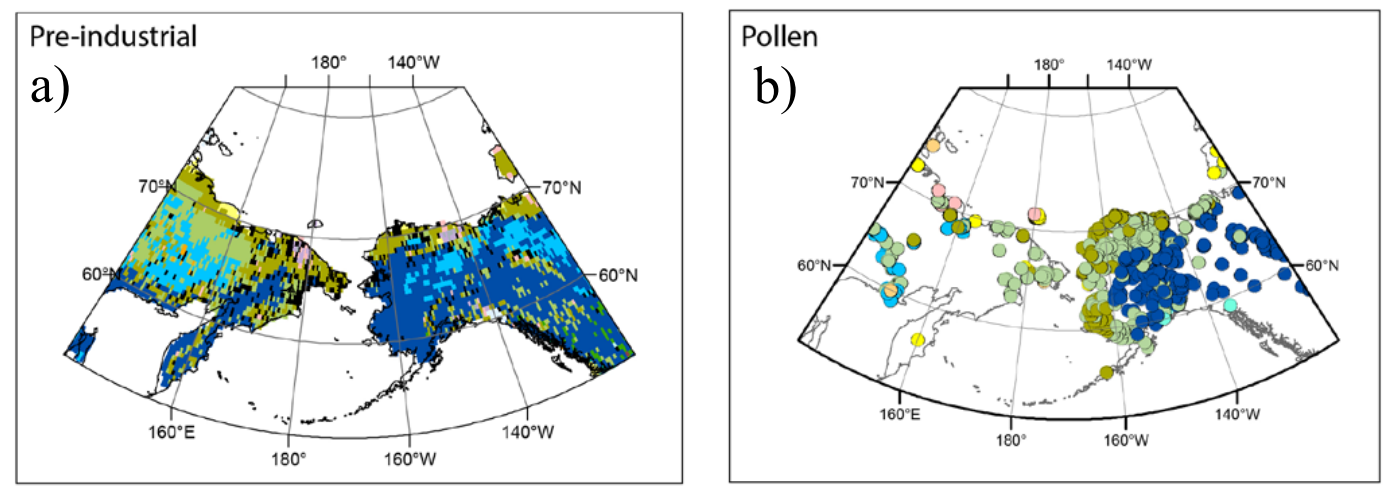

\section{Pre-Industrial}

\begin{tabular}{|c|c|}
\hline No concensus & Low and high shrub tundra \\
\hline Ice & Graminoid and forb tundra \\
\hline Barren & Deciduous taiga \\
\hline Cushion-forb tundra & Evergreen taiga \\
\hline Prostrate dwarf shrub tundra & Cool mixed forest \\
\hline Erect dwarf shrub tundra & Cool conifer forest \\
\hline
\end{tabular}

$\square$ Cool-temperate mixed forest
Temperate conifer forest
Warm-temperate mixed forest
Temperate shrubland or woodland
Temperate grassland
Desert

\section{fig05}


Clim. Past Discuss., https://doi.org/10.5194/cp-2018-29

Manuscript under review for journal Clim. Past

Discussion started: 3 April 2018

(c) Author(s) 2018. CC BY 4.0 License.

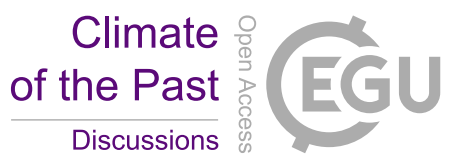

(c) (i)
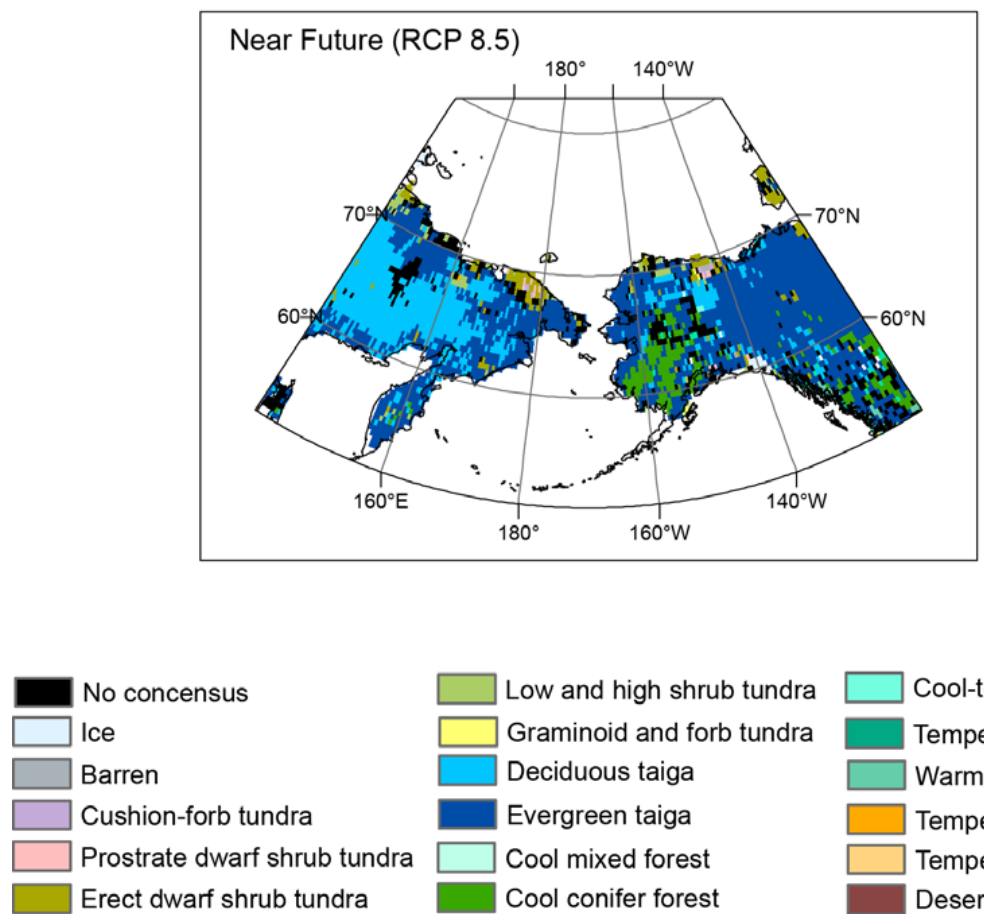

$\square$ Low and high shrub tundra
$\square$ Graminoid and forb tundra
Deciduous taiga
Evergreen taiga
$\square$ Cool mixed forest
Cool conifer forest

$\square$ Cool-temperate mixed forest
Temperate conifer forest
Warm-temperate mixed forest
$\square$ Temperate shrubland or woodland
$\square \quad$ Temperate grassland
Desert

\section{fig06}


Clim. Past Discuss., https://doi.org/10.5194/cp-2018-29

Manuscript under review for journal Clim. Past

Discussion started: 3 April 2018

(c) Author(s) 2018. CC BY 4.0 License.

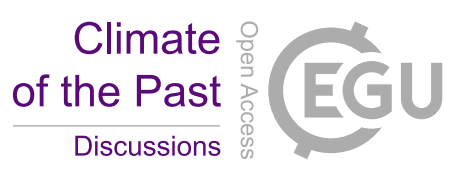

(c) (i)

a)

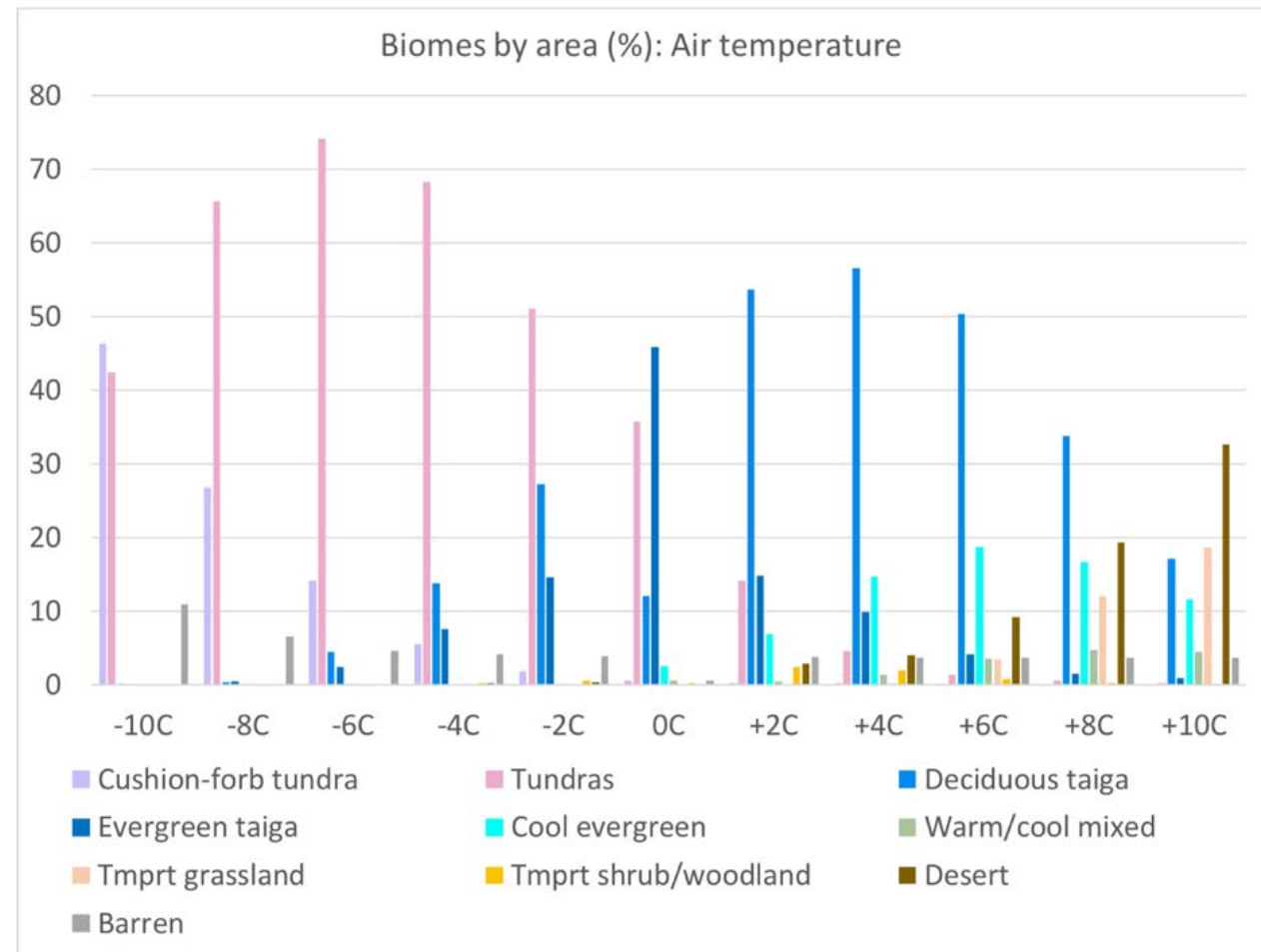

b)
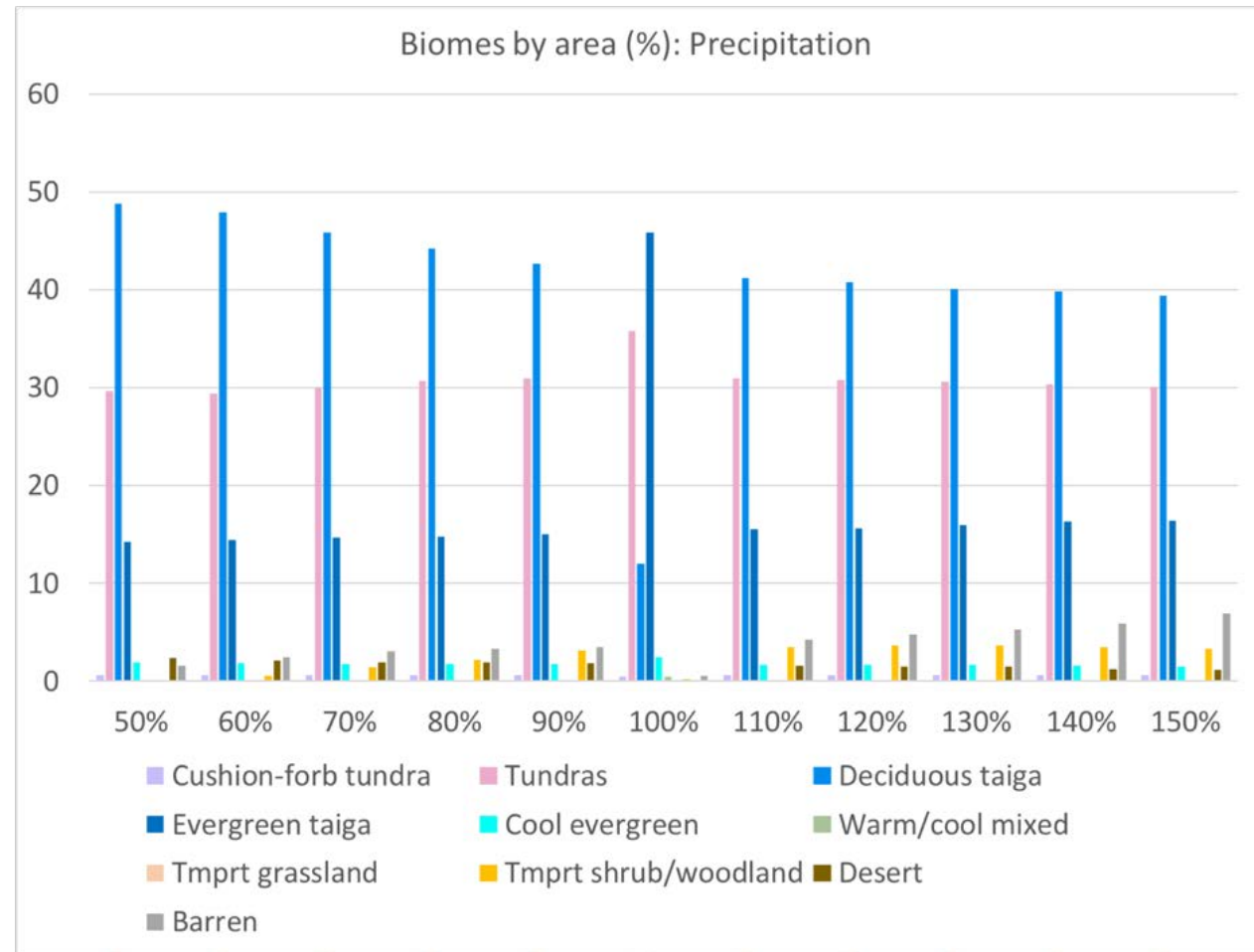
Clim. Past Discuss., https://doi.org/10.5194/cp-2018-29

Manuscript under review for journal Clim. Past

Discussion started: 3 April 2018

(c) Author(s) 2018. CC BY 4.0 License.

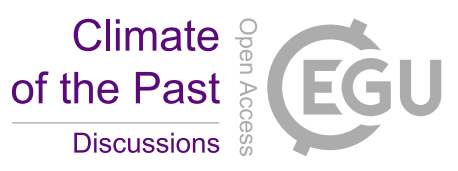

(c)

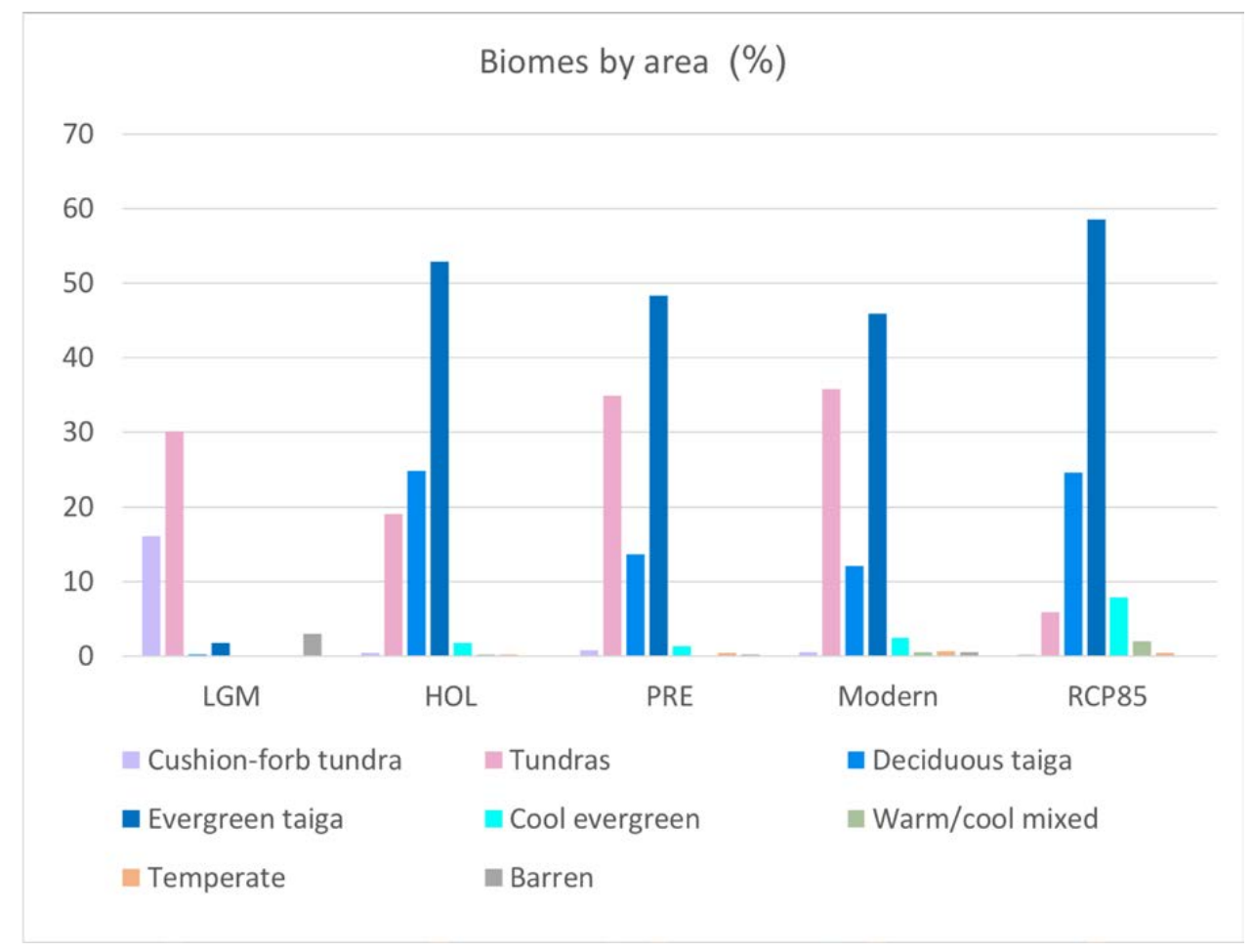

fig08 